\title{
Operations and Maintenance Cost for Stratified Buildings: A Critical Review
}

\author{
Nor Zaimah Che-Ghani ${ }^{1}$ Nik Elyna Myeda ${ }^{1, a}$ and Azlan Shah Ali ${ }^{1}$ \\ ${ }^{1}$ Department of Building Surveying, Faculty of Built Environment, University of Malaya, Kuala Lumpur
}

\begin{abstract}
Building maintenance is essential in preserving buildings' appearance and performance. It needs to upkeep the building performance to prolong its value and building life cycle. Malaysia is still lacking in managing cost for building operation and maintenance. It has been found that the cost for housing maintenance is high due to poor maintenance practices. In order to get better understanding on how to manage the cost, this study reviews the contributing factors that affecting operation and maintenance cost of stratified buildings in Malaysia. The research first identified the factors through extensive literature review and scrutinize on factors that affecting and can minimize operation and maintenance cost. This literature review offers insight into building maintenance scenario in Malaysia focusing on the issues and challenges. The study also finds that operation and maintenance cost for housing in Malaysia is still in poor state. Interestingly, this paper revealed that operation and maintenance cost is also influenced by three significant factors like expectation of tenants, building characteristics and building defects. Measures to reduce the housing operation and maintenance cost are also highlighted so that this study can be a stepping stone towards proposing efficient and effective facilities management strategies for affordable housing in future.
\end{abstract}

\section{Introduction}

Buildings have been considered as one of the most valuables assets of a nation to provide people with shelter and facilities for work and leisure. As time passes by, maintenance of buildings becomes an invaluable process in retaining the value and quality of a building [26]. In Britain, building maintenance activities have reached a level of 50 per cent of all annual construction activities [3, 27]. In Hong Kong, the gross value of general trades such as decoration, repair and maintenance, and construction work at minor work locations has increased over the past five years [11]. Buildings are relatively expensive and time-consuming to procure and usually have a service life in many decades rather than in years. Buildings, however, are not static over time; they change, evolve and often adapt in response both to external factors such as climate, exposure and, more significantly, internal factors such as use and maintenance [6].

BS 3811 defined maintenance as a combination of any actions in order toretain an item in, or restore it to an acceptable condition [28]. Building maintenance as defined by The Chartered Institute of Building is a work undertaken to keep, restore or improve every facility in every part of a building, its services and surrounds to an agreed standard, determined by the balance between the need and available resources. It requires all departments in an organisation to cooperate in ensuring that the assets of the organizations are planned, provided, maintained, operated and disposed off at the lowest total cost to the organization [28]. According to Horner et al. [9], the objectives of building maintenance are:

\footnotetext{
${ }^{\mathrm{a}}$ Corresponding author: elyna@um.edu.my
}

- To ensure that the buildings and their associated services are in a safe condition

- To ensure that the buildings are fit for use

- To ensure that the condition of the building meets all statutory requirements

- To carry out the maintenance work necessary to maintain the value of physical assets of the building stock, and

- To carry out the work necessary to maintain the quality of the building

The Prime Minister Department has given an instruction under the 'Pekeliling Am Bil 1 Tahun 2003, Arahan Penyelenggaraan Bangunan Kerajaan di Putrajaya dated February $11^{\text {th }} 2003$," building maintenance must be efficiently and properly executed but most of current building and facilities maintenance management in Malaysia is not considered clearly and systematically [16]. The Government has also given instructions to all their agencies to carry out maintenances of all their building in the very early stage so that to reduce the cost of maintenances and to avoid risk of higher maintenance cost due to negligent through time. But, very less attention has been given on building maintenance budget and it is very rare to see research carried out on the subject of maintenance expenditure, funding or financial budget of maintenance work [14]. In year 2006 repair and maintenance works constituted $16 \%$ of the total Malaysian construction output as reported by CIDB (2007). However there are still unreported maintenance works by house owners who carried out illegal renovation works. Thus, if 
this figure is taken into account, the actual value of repair and maintenance works in Malaysia would be higher [2].

\section{Operations and Maintenance Management}

Maintenance management or operations management are utilised to transform input including people, capital, energy, materials and technology into outputs (goods and services) [7]. Maintenance and operating cost is one of the major components of housing cost and contributes one third to one half of total cost depending on the type of housing such as condominium, apartment, flat and others $[3,29]$. It has been reported that between $70 \%$ and $85 \%$ of the building maintenance and operation costs can be influenced during the design stage. It is a significant part of the total building life cycle costs and awareness towards planning building maintenance and operation cost has been increased recently $[10,30,31]$.

More than $90 \%$ of the building life cycle requires active maintenance and the full service life of building cannot be attained without maintenance [17]. The easiest way to cut maintenance costs is to stop doing maintenance but the long-term results are usually very costly. Thus, the goal of the new approach is to carry out as little maintenance as possible as infrequently as possible while at the same time preserving the availability of the services facilities, the building elements and the whole building. In other words, maintenance should be carried out only when necessary to ensure the continued, safe and profitable use of the building at acceptable levels of satisfaction or when there is the possibility of extending the useful life of the elements of the building [9].

Maintenance strategy is adopted in order to extend the life cycle of buildings and its fitting services. Maintenance personnel choose different maintenance strategies depending on allocation maintenance resources [12]. In maintaining a building, there are usually several strategic options available to management, and many alternative decisions to be considered. There is, for example, the possibility of reducing the demand for maintenance by addressing the actual cause of failure and identifying its consequences. For instance, it may be necessary to decide whether to repair or replace an item, and whether to carry out periodic maintenance at fixed intervals or simply to respond to the requests of the users [9].

In order to get the efficient and lowest long term cost of ownership for equipment or a project, life cycle cost (LCC) analysis is a crucial tool to choose the most costeffective approach from a series of alternatives. The alternatives might be selected from different companies or tenders [3]. LCC is the total relevant costs over the life of a system including cost of acquisition, operation, maintenance, modification, and disposal for the purpose of making decision [32]. LCC takes into account initial and other running costs (total cost of operation and maintenance of a system) over a life of the buildings. It can help in determining how the owner's money is distributed during the life period of the facility and determine the most economic way of meeting a need of space. The earlier it is applied, the greater the possibility of saving and lowering the committed cost. It is used to identifying high cost areas and evaluating changes that will reduce these costs $[4,33]$.

The life cycle approach attempts to estimate future maintenance and repair requirements by breaking down each facility into its systems and components (electrical, HVAC, roofing, etc.) and independently applying lifeexpectancy or life cycle concepts to each system and components [18]. Although a large number of life cycle cost models have been developed over the years, no single life cycle cost model has been accepted as a standard model. such standard model has not been established for several reasons, including the existence of many different cost data collection systems, and many different types of equipment, devices, or systems [10,31].

Building performance is the ability of the building to support its design functions and the criteria of building performance include indoor climate, acoustics, lighting, flexibility, safety, comfort, security, convenience, indoor air quality, glare, accessibility, aesthetics, etc [17]. Buildings, services and facilities require maintenance to ensure optimal performance over their life cycle [34]. Though existing building simulation software can be used to study building performance, costs and energy consumption, yet they are limited to static building with no responsive elements. Previous studies have shown that digital simulation outcome at design stage do not contribute to enhance building performance after been occupied. This is due to inaccuracy of data from digital simulation experiments at early design stages [35].

\subsection{Building maintenance scenario in Malaysia}

Most current building and facilities maintenance management being practiced in Malaysia is not considered clearly and systematically, which results in over-budget costs for maintenance and remedial work [21]. As an example, 34 office buildings in Property Division of SOCSO around Malaysia has been dealing with the common maintenance problems and building defects on civil and structural elements like problems involving water proofing system, cracks, soil settlement and so on [23]. The failures found in the adoption and implementation of FM in Malaysia can be categorized into four factors as in Table 1 (FM failures on managing building features).

The government has played a major role in the development of FM in Malaysia since it started in the second half of 1990s. In 1996, the government has privatized the non-clinical support services in the government hospitals to three FM companies.

Table 1. FM failures on managing buiding features (Mustaffa $e t$ al., 2008)

\begin{tabular}{|c|c|}
\hline $\begin{array}{l}\text { Failing } \\
\text { factors }\end{array}$ & Description \\
\hline $\begin{array}{l}\text { Tactical } \\
\text { failing }\end{array}$ & $\begin{array}{ll} & \text { Inadequate performance standard } \\
\text { - } & \text { Low maintenance of cleaning standards } \\
\end{array}$ \\
\hline $\begin{array}{l}\text { Strategic } \\
\text { environmenta } \\
1 \text { failings }\end{array}$ & $\begin{array}{l}\text { Lack of building performance } \\
\text { monitoring data } \\
\text { - Failure to anticipate the consequences } \\
\text { of change } \\
\text { - Failure to understand the non-linear } \\
\text { nature of building complexity }\end{array}$ \\
\hline
\end{tabular}




\begin{tabular}{|l|ll|}
\hline & $\bullet$ & Slow response of systems used \\
\hline $\begin{array}{l}\text { Tactical } \\
\text { cultural } \\
\text { failings: }\end{array}$ & $\bullet$ & $\begin{array}{l}\text { Responding slowly to complaints } \\
\text { Ignorance job stress }\end{array}$ \\
\hline $\begin{array}{l}\text { Strategic } \\
\text { cultural } \\
\text { failings: }\end{array}$ & $\bullet \begin{array}{l}\text { Failure to provide appropriate advise } \\
\text { on design and planning based on } \\
\text { overall performance }\end{array}$ \\
\hline
\end{tabular}

It was indeed the biggest FM contract by the government at that time. It also marked the starting of the new era of FM in Malaysia. In February 2001, during the opening of the Kuala Lumpur 21 Convention and exposition, the then Deputy Prime Minister of Malaysia in referencing to the state of FM in Malaysia emphasized that [24]:

"Unless Malaysians change their mentality to become more aware of the need to provide good services and improve the upkeep of buildings, we will forever be a Third World country with First World Infrastructure"

The former Prime Minister of Malaysia, Datuk Seri Abdullah Ahmad Badawi says that it is very common to see that most government buildings were not regularly maintained because most faults cannot be distinguished at their early stage. On this basis, he has suggested that the Public Work Department needs to prepare building maintenance guidelines in order to identify any damage from the early stage [22].

\section{Methodology}

The paper systematically categorised the published literature as in Table 2 and then analyse and reviews it methodically. The list of factors are analysed through a theoretical part that discusses on operation and maintenance cost of stratified buildings. Table 3 lists down all the factors that affecting operation \& maintenance costs by El-Haram \& Horner [39], Ali et al. [3], Assaf et al. [40] and Al-Hammad et al. [1]. El-Haram \& Horner [39] and Ali et al. [3] directly highlight on contributing factors affecting operation and maintenance costs. Assaf et al. [40] and Al-Hammad et al. [1] discusses on how faulty design effect on building maintenance which will later result in high maintenance cost.

\section{Contributing Factors Affecting Operation and Maintenance Costs}

Maintenance and operation costs are a part of the building's life cycle cost. Maintenance costs cover the cost of labour and material, as well as other related costs that are incurred to keep the building or its parts in the state in which it can perform its required functions. Maintenance implies the conduct of corrective, responsive and preventive maintenance activities on constructed assets, or on some parts of these assets. Operation costs include running costs and costs of managing the facility or built environment, including administrative support services (e.g. rent, rates, insurances, energy and other environmental/regulatory inspection cost, local taxes and charges) [10].

The study of the academic literature of research on contributing factors of building maintenance cost is shows in Table 4. The critical contributing factors that can be summarized from this literature are building characteristics, tenant factors, maintenance factors, political factors and others. Previous study by Ali et al. [3] was conducted based on El-Haram \& Horner [39], the difference between these two studies are Ali et al.[3] analysed all critical factors include building characteristics. Meanwhile, El-Haram \& Horner [39] only covers tenant factors, maintenance factors, political factors and others. But, both studies from Ali et al. [3] and ElHaram \& Horner [39] found that expectation of tenants (tenant factor) is the most critical factors that contribute to operation and maintenance cost. Fakhrudin et al. [41] opined that the activities and attitudes of residents in strata living can have a significant impact on the satisfaction and enjoyment of others. Strata living are not the same as living in a freestanding house. The activities and attitudes of residents can have a significant impact on the satisfaction and enjoyment of others [15]. People are expecting and demanding more from their building nowadays and the residents are becoming less tolerant and require their buildings to be perfect, facilities that will be comfortable to occupy, cost-effective and efficient to run, and will remain added value assets [6].

Building characteristics like building materials, building services and building age were ranked as second, third and fourth respectively of the factors that affect building maintenance cost in Ali et al. [3] study. Buildings are very durable and if properly maintained may last for centuries. Even if maintenance is indifferent, a physical life of 50-60 years is quite realistic [36]. Maintenance is essential to maintain the value of the building [4, 17]. Table 5 shows the range of actual lifespan of the high-rise residential buildings vary considerably between countries, the highest being in Britain as reported by Shabha [19] and relationship between maintenance costs and the age of a building is collected by Mac-Barango and Kakulu [13]. It shows an increasing maintenance cost trend with age. 


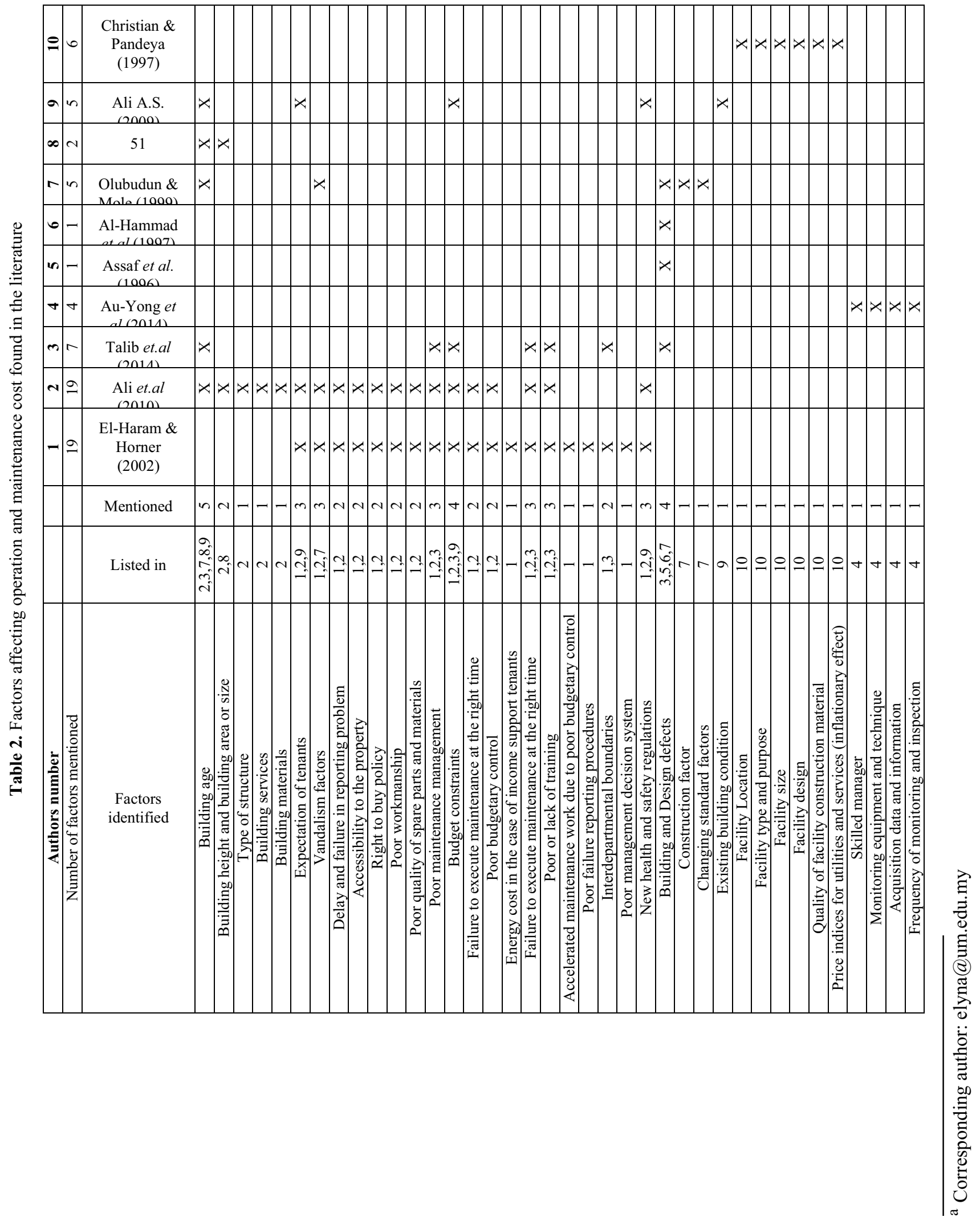




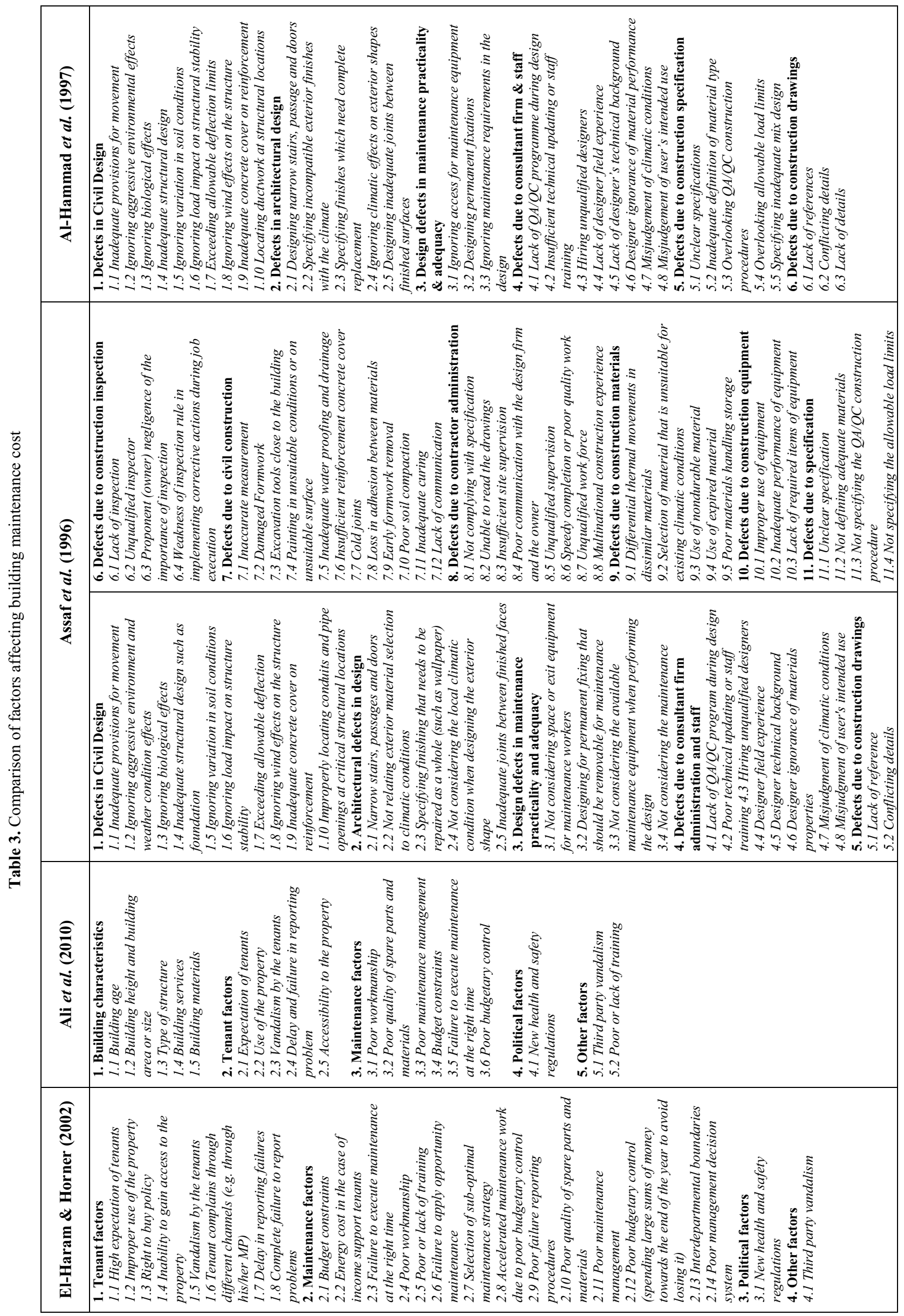


The charts in Figure 1 show progressive increases in maintenance cost according the category of age of the building. The less lifespan of buildings show lower maintenance costs.

Table 5. A comparison of the life cycle of high rise residential buildings in different countries

\begin{tabular}{|c|c|}
\hline Countries & Buildings' life span \\
\hline New Zealand & $50-60$ \\
\hline Australia & $50-60$ \\
\hline Britain & 60 \\
\hline USA & 35 \\
\hline Japan & 20 \\
\hline
\end{tabular}

Source: Shabha [19]

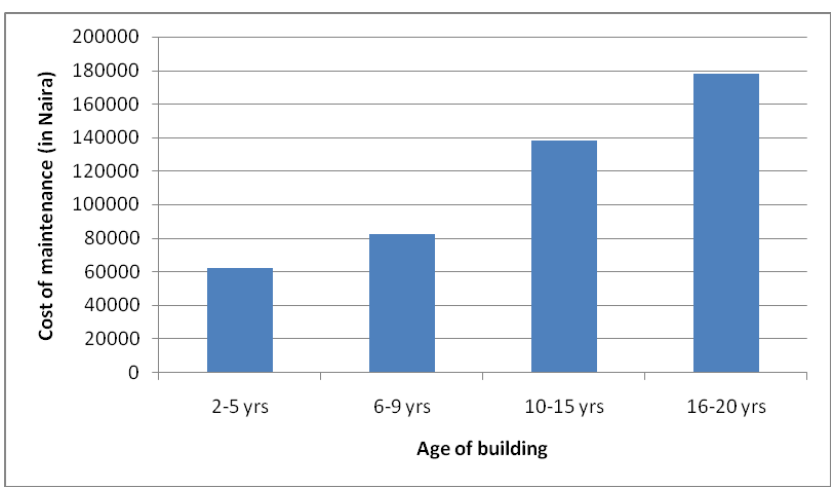

Figure 1. Variation maintenance costs based on building ages Source: Mac-Barango and Kakulu [13]

Besides that, Al-Khatam [4] also agreed that behaviour of materials as one of the major causes of building deterioration and other unsatisfactory features of many buildings. Materials selection should meet the performance requirements otherwise it will cause failure of the materials which will result in replacement, correction or more maintenance works in the future.

Table 4. Collection of previous studies on building maintenance cost

\begin{tabular}{|c|c|c|c|}
\hline Margin & El-Haram \& Horner (2002) & Ali et al. (2010) & Talib et al. (2014) \\
\hline Scope & Maintenance cost & Maintenance cost in Malaysia & $\begin{array}{l}\text { Factor affecting maintenance and } \\
\text { defects of public building }\end{array}$ \\
\hline Aim & $\begin{array}{l}\text { Describes the objectives of building } \\
\text { maintenance and principal elements } \\
\text { of housing maintenance cost }\end{array}$ & $\begin{array}{l}\text { To determine and identity the factors } \\
\text { contributing to rising maintenance } \\
\text { costs. }\end{array}$ & $\begin{array}{l}\text { This study focuses on the assessment } \\
\text { of factors affecting maintenance and } \\
\text { defects of public buildings in } \\
\text { Penang. }\end{array}$ \\
\hline Emphasis & $\begin{array}{l}\text { Identify the extent to which } 24 \\
\text { factors impede the optimum } \\
\text { application of maintenance cost }\end{array}$ & $\begin{array}{l}\text { The research was conducted based } \\
\text { on the work undertaken by El-Haram } \\
\& \text { Horner [39]. }\end{array}$ & $\begin{array}{l}\text { The summary of ten relevant factors } \\
\text { surveyed from related literatures } \\
\text { were tabled and questioned to whom } \\
\text { involved in the building maintenance } \\
\text { sectors. }\end{array}$ \\
\hline Focus & $\begin{array}{l}\text { Factors affecting } \quad \text { housing } \\
\text { maintenance cost }\end{array}$ & $\begin{array}{l}\text { Factors affecting housing } \\
\text { maintenance cost in Malaysia }\end{array}$ & $\begin{array}{l}\text { Factors affecting maintenance and } \\
\text { defects of public buildings in } \\
\text { Penang. }\end{array}$ \\
\hline Methodology & Quantitative (Questionaire) & Quantitative (Questionaire) & $\begin{array}{l}\text { Questionnaire } \\
\text { SPSS }\end{array}$ \\
\hline Sample & $\begin{array}{l}\text { Local authority and housing } \\
\text { associations throughout Scotland. }\end{array}$ & $\begin{array}{l}\text { Housing maintenance management } \\
\text { in Klang Valley, Malaysia }\end{array}$ & $\begin{array}{llr}\text { public buildings } & \text { are } \\
\text { demographically } & \text { centralized } & \text { in } \\
\text { Penang } & & \\
\end{array}$ \\
\hline Framework & Factors - Measures & $\begin{array}{l}\text { Factors } \quad-\quad \text { Impact/Influence } \quad- \\
\text { Measure }\end{array}$ & Factors -Defects \\
\hline Indicators & $\begin{array}{l}\text { Building characteristics } \\
\text { Tenant factors } \\
\text { Maintenance factors } \\
\text { Political factors } \\
\text { Other factors } \\
\end{array}$ & $\begin{array}{l}\text { Building characteristics } \\
\text { Tenant factors } \\
\text { Maintenance factors } \\
\text { Political factors } \\
\text { Other factors } \\
\end{array}$ & $\begin{array}{l}\text { Factors affecting maintenance of } \\
\text { public building } \\
\text { Factors affecting defects of public } \\
\text { building }\end{array}$ \\
\hline Findings & $\begin{array}{l}\text { Rank } 1 \text { - high expectation of tenants } \\
\text { (tenant factors) } \\
\text { Rank } 2-\text { budget constraints } \\
\text { (maintenance factors }- \text { technical } \\
\text { factors) } \\
\text { Rank } 3-\text { improper use of the } \\
\text { property (tenant factors) } \\
\text { Rank } 4 \text { - energy cost in the case of } \\
\text { income support tenants (other } \\
\text { factors) }\end{array}$ & $\begin{array}{l}\text { Rank } 1-\text { expectation of tenants } \\
\text { (tenant factors) } \\
\text { Rank } 2-\text { Building materials } \\
\text { (Building characteristics) } \\
\text { Rank } 3 \text { - Building services (Building } \\
\text { characteristics) } \\
\text { Rank } 4-\text { Building age (Building } \\
\text { characteristics) }\end{array}$ & $\begin{array}{l}\text { Factors affecting maintenance: } \\
\text {-Lack of preventive maintenance } \\
\text {-Insufficient funds to maintain the } \\
\text { building } \\
\text {-Lack of building maintenance } \\
\text { standard } \\
\text {-Non-availability of replacement } \\
\text { part and components } \\
\text {-Not responded to maintenance } \\
\text { request }\end{array}$ \\
\hline
\end{tabular}




\begin{tabular}{|c|c|c|c|}
\hline & $\begin{array}{l}\text { Rank } 5-\text { right to buy policy } \\
\text { (political factors) }\end{array}$ & $\begin{array}{l}\text { Rank 5- Failure to execute } \\
\text { maintenance at the right time } \\
\text { (Maintenance factors) } \\
\text { Impact: } \\
\text { Rank 1 - outstanding maintenance } \\
\text { charges } \\
\text { Rank 2 - Over budget }\end{array}$ & $\begin{array}{l}\text { Factors of building defect:: } \\
\text {-Lack of building maintenance, } \\
\text {-Overlooked site conditions, } \\
\text {-Defective material, } \\
\text {-Environment conditions and } \\
\text {-Moisture from wet areas. }\end{array}$ \\
\hline Output & $\begin{array}{l}\text { Establish the relative importance of } \\
\text { the factors which affect housing } \\
\text { maintenance costs }\end{array}$ & $\begin{array}{l}\text { Framework of maintenance cost } \\
\text { contributing factors and impact on } \\
\text { maintenance performance }\end{array}$ & $\begin{array}{l}\text { Concluded that buildings allocated } \\
\text { within the Equatorial region are } \\
\text { exposed to extreme hot and wet } \\
\text { climate and must have proper } \\
\text { maintenance schedule and } \\
\text { guidelines }\end{array}$ \\
\hline Comments & $\begin{array}{l}\text { The study neglect factor of building } \\
\text { characteristics since it has already } \\
\text { been studied. Tenants factor is } \\
\text { uncontrollable (nature of tenants \& } \\
\text { environment). }\end{array}$ & $\begin{array}{l}\text { Each factors was describe neatly. } \\
\text { Impacts on maintenance } \\
\text { performance was also analysed. } \\
\text { Although the research was } \\
\text { conducted base on El-Haram \& } \\
\text { Horner [39], the result is not similar. } \\
\text { This study includes building } \\
\text { characteristics and building } \\
\text { characteristics do affect maintenance } \\
\text { cost. }\end{array}$ & $\begin{array}{l}\text { This study have been present state of } \\
\text { non maintenance public building, } \\
\text { some of which have been abandoned } \\
\text { due to its state of defects. Authors } \\
\text { recommend appropriate building } \\
\text { maintenance strategy to be taken. In } \\
\text { order to preserve this type of } \\
\text { building(heritage building), it will } \\
\text { take huge money. }\end{array}$ \\
\hline
\end{tabular}

Table 4. Collection of previous studies on building maintenance cost (continued)

\begin{tabular}{|c|c|c|c|}
\hline Margin & Au-Yong et al.(2014) & Assaf et al. (1996) & Al-Hammad et al.(1997) \\
\hline Scope & $\begin{array}{l}\text { Condition- Based Maintenance: } \\
\text { prediction cost maintenance model }\end{array}$ & $\begin{array}{lrr}\begin{array}{l}\text { Effects of faulty } \\
\text { construction } \\
\text { maintenance }\end{array} & \text { on } & \begin{array}{r}\text { design and } \\
\text { building }\end{array} \\
\end{array}$ & $\begin{array}{l}\text { Civil and architectural defects in } \\
\text { building design that affect } \\
\text { maintenance }\end{array}$ \\
\hline Aim & $\begin{array}{l}\text { This paper seeks to establish the } \\
\text { relationships between the } \\
\text { characteristics of condition-based } \\
\text { maintenance and the cost } \\
\text { performance. }\end{array}$ & $\begin{array}{l}\text { This paper outlines individual and } \\
\text { major groups of design and } \\
\text { construction defects in large } \\
\text { buildings in Saudi Arabia and their } \\
\text { relative severity. }\end{array}$ & $\begin{array}{l}\text { To identify design defects which } \\
\text { affect building maintenance and } \\
\text { their overall relative importance. }\end{array}$ \\
\hline Emphasis & $\begin{array}{l}\text { This study focuses on the issue } \\
\text { related to the building users' } \\
\text { dissatisfaction in high-rise office } \\
\text { buildings. }\end{array}$ & $\begin{array}{l}\text { These studies indicate the } \\
\text { percentage contribution of defects to } \\
\text { building maintenance. }\end{array}$ & $\begin{array}{l}\text { It is based on the opinion of parties } \\
\text { most concerned with building } \\
\text { maintenance (contractors, designers } \\
\text { \& owners) }\end{array}$ \\
\hline Focus & $\begin{array}{l}\text { Relationship between } \\
\text { Characteristics of Condition-Based } \\
\text { Maintenance and Cost Performance }\end{array}$ & $\begin{array}{l}\text { Faults in design that affect building } \\
\text { maintenance }\end{array}$ & $\begin{array}{l}\text { Faults in design that affect building } \\
\text { maintenance }\end{array}$ \\
\hline Methodology & $\begin{array}{l}\text { Mix method (questionnaire, survey, } \\
\text { interview, case study) }\end{array}$ & $\begin{array}{l}\text { Literature search and Interview } \\
\text { Questionnaire }\end{array}$ & $\begin{array}{l}\text { Literature } \\
\text { Mixed Method }\end{array}$ \\
\hline Sample & $\begin{array}{l}\text { Klang Valley, Malaysia } \\
\text { Kuala Lumpur }\end{array}$ & Eastern Province of Saudi Arabia & $\begin{array}{l}\text { (owners, A/Es and contractors) } \\
\text { Eastern Province of Saudi Arabia }\end{array}$ \\
\hline Framework & Characteristics - Cost Performance & Defects in design & Defects in design \\
\hline Indicators & $\begin{array}{l}\text { Skilled manager } \\
\text { Monitoring equipment and technique } \\
\text { Acquisition data and information } \\
\text { Frequency of monitoring and } \\
\text { inspection }\end{array}$ & $\begin{array}{l}\text { Defects in Civil Design } \\
\text { Architectural defects in design } \\
\text { Design defects in maintenance } \\
\text { practicality and adequacy } \\
\text { Defects due to consultant firm } \\
\text { administration and staff } \\
\text { Defects due to construction } \\
\text { drawings } \\
\text { Defects due to construction } \\
\text { inspection } \\
\text { Defects due to civil construction } \\
\text { Defects due to contractor } \\
\text { administration }\end{array}$ & $\begin{array}{l}\text { Defects in Civil Design } \\
\text { Defects in architectural design } \\
\text { Design defects in maintenance } \\
\text { practicality \& adequacy } \\
\text { Defects due to consultant firm \& } \\
\text { staff } \\
\text { Defects due to construction } \\
\text { specification } \\
\text { Defects due to construction drawings }\end{array}$ \\
\hline
\end{tabular}




\begin{tabular}{|c|c|c|c|}
\hline & & $\begin{array}{l}\text { Defects due to construction } \\
\text { materials } \\
\text { Defects due to construction } \\
\text { equipment } \\
\text { Defects due to specification }\end{array}$ & \\
\hline Findings & $\begin{array}{l}\text { The findings revealed that the } \\
\text { characteristics of condition-based } \\
\text { maintenance directly influenced the } \\
\text { cost performance }\end{array}$ & 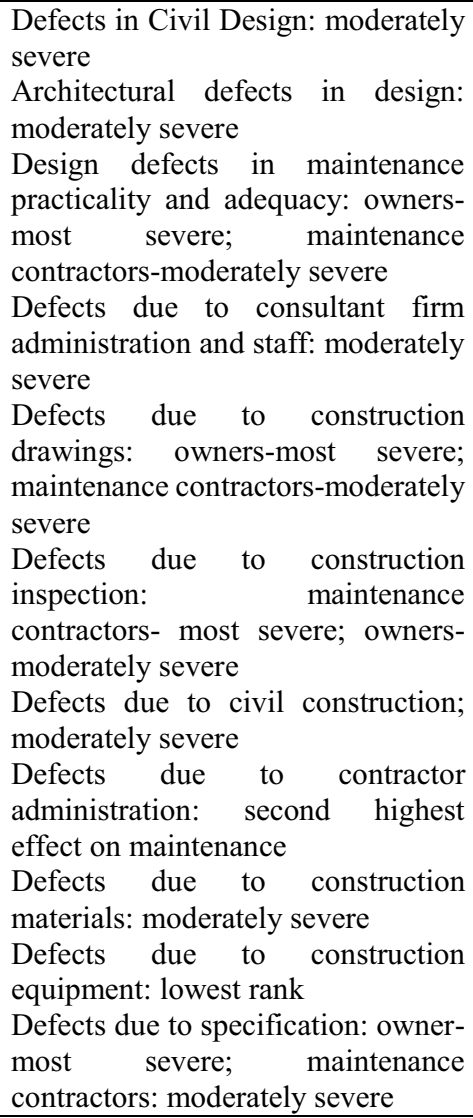 & 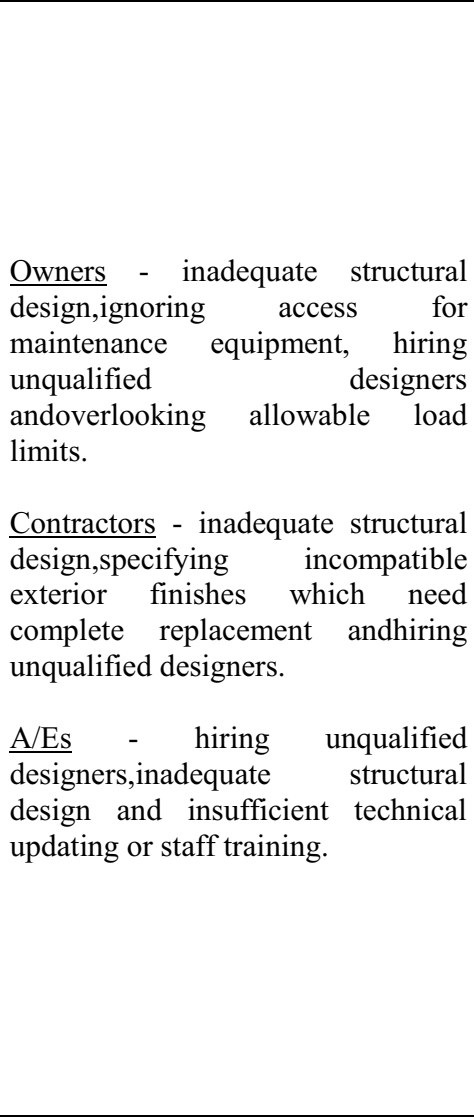 \\
\hline Output & $\begin{array}{l}\text { Skill and knowledge manager, } \\
\text { availabilityof monitoring equipment } \\
\text { and technique, capability to adopt } \\
\text { monitoringtechnology, as well as } \\
\text { reliability of maintenance data and } \\
\text { informationwere highlighted as the } \\
\text { characteristics that significantly } \\
\text { influencingthe } \\
\text { performance. } \\
\text { Using the prediction model, } \\
\text { practitioners can predict the } \\
\text { varianceof maintenance expenditure } \\
\text { from the level of concern towardsthe } \\
\text { reliability of maintenance data. Thus, } \\
\text { they may decide how muchof } \\
\text { concern towards the reliability of } \\
\text { maintenance data is required inorder } \\
\text { to achieve optimal maintenance } \\
\text { expenditure. }\end{array}$ & $\begin{array}{l}\text { Both parties (owners and } \\
\text { maintenance contractors) ranked } \\
\text { "defects due to contractor } \\
\text { administration" among the highest } \\
\text { effect on maintenance. All defects in } \\
\text { this group were ranked "most } \\
\text { severe" by each with the exception } \\
\text { of the lack of multinational } \\
\text { construction experience and poor } \\
\text { communication which were rated } \\
\text { "moderately severe' by the } \\
\text { maintenance contractors. }\end{array}$ & $\begin{array}{l}\text { To improve building maintenance: } \\
\text {-provide adequate structural design } \\
\text {-Provide proper access to } \\
\text { maintenance equipment } \\
\text {-Provide proper exterior finishes } \\
\text { compatible with climate conditions } \\
\text {-hire qualified designers } \\
\text {-provide sufficient detail in } \\
\text { construction drawings. }\end{array}$ \\
\hline Comments & $\begin{array}{l}\text { This maintenance strategy is aimed } \\
\text { to minimise the total maintenance } \\
\text { cost by collecting and gathering the } \\
\text { condition data of the building } \\
\text { systems, especially those critical } \\
\text { components. }\end{array}$ & $\begin{array}{l}\text { This paper is similar to Al-Hammad } \\
\text { et al [1] but it only reviewed based } \\
\text { on owners and maintenance } \\
\text { contractor. }\end{array}$ & $\begin{array}{l}\text { Error and defects occur during } \\
\text { design \& construction stages will } \\
\text { result later in high maintenance } \\
\text { costs. Untreated defects is Rank } 3 \text { of } \\
\text { impact on maintenance performance } \\
\text { as in analysed by Ali et al. (2010). }\end{array}$ \\
\hline
\end{tabular}


Building services is a vital aspect in building maintenance management that affect housing maintenance costs. It is to provide a healthy and safe living environment for occupants or residents. The building services include mechanical and electrical services like ventilation, lighting and power supply, water supply, sanitation, transportation communication and other systems [37]. Owing to the high maintenance cost involved and the consequences of building services' failure, awareness on the significance of the building services maintenance has increased in the building services industry [3]

The quality of maintenance activities like labour productivity, material availability, materials waste, good and effective maintenance methods, using effective tools and equipment, and good maintenance planning is influenced by the amount of budget allocation in each task. Maintenance management should be aware of these factors in order to achieve better financial control [2,4]. An earlier study by Holmes \& Droop [42] stated that "maintenance is budget oriented rather than needs-oriented". This led Ashworth and Au-Yeung [43] conclude that maintenance will only be carried out when and where the needs for maintenance and adequate funding co-exist [38]. Due to budget and time constraint, many errors and defects have occurred during the design and construction stage which will result in high maintenance cost later [1]. Shabha [19] stated that cutting cost at the initial design and construction stages has led to a significant increase in the long term cost of replacing faulty components and running cost. This has made many high-rise buildings energy inefficient and their design has proven to be costly for occupiers. Previous studies by Al-Hammad et al. [1] improved on the research from Assaf et al. [40] where they discussed on building defects that affecting building maintenance and will result later in high maintenance costs. Error and defects occur during design \& construction stages will result later in high maintenance costs As example state in Al-Hammad et al. [1], it is noted that contractors, architects/engineers and owners agree inadequate structural design the significant design defect. Inadequate structural design occurs when the designer under-designs the structural elements in the building. This can cause a building's settlement or cracking, or collapse which can increase maintenance cost. Inadequate structural design is a controllable factor that can be avoided and can minimize maintenance cost.

\section{Conclusions}

An extensive literature review was conducted and authors concluded that operation and maintenance costs are influenced by uncontrollable factor like expectation of tenants and building characteristics. It can be summarised that inadequate structural design is the significant design defect which will be affected by maintenance cost in future. Inadequate structural design (design defect) is a controllable factor that can be avoided to minimise the operation and maintenance cost. Uncontrollable factors like tenant factors might be difficult to control because of the nature of human behaviour. In summary, various measures to minimise building operation and maintenance costs are as follows:
- Tenants and residents should be educated on the community well-being awareness

- Buildings should be preserved in the early stage

- Employing minimum, but optimum labour and staff with acceptable qualification standards

- Maintain and repair on urgent and on time tasks before further implication or defect occurs

- Development of adequate maintenance management information education program.

- Introducing operation and maintenance operating manual

- For less critical maintenance; corrective maintenance technique is suggested

- Apply preventive maintenance technique with the scheduled work in preparation of breakdowns or failures.

- $\quad$ Reducing the number of maintenance tasks by selecting the most applicable and cost-effective maintenance strategies

Looking forward, this study also signifies its significant factor in exploring the cost variance and factor, not just limited to the context of stratified buildings. A theoretical framework will be developed to construct a better understanding of the theories for this study.

\section{Acknowledgement}

The authors gratefully acknowledge the financial support of the University of Malaya Research Grant (UMRG), grant no. RP015D-15SUS established at the University of Malaya, Sustainability Science Research Cluster.

\section{References}

1. A. Al-hammad, S. Assaf, \& M. Al-shihah, The effect of faulty design on building maintenance. Journal of Quality in Maintenance Engineering, 3(1), 29-39. (1997)

2. A. S. Ali, Cost decision making in building maintenance practice in Malaysia. Journal of Facilities Management, 7(4), 298-306 (2009)

3. A. S. Ali, S. N. Kamaruzzaman, R. Sulaiman, Y. Cheong Peng, Factors affecting housing maintenance cost in Malaysia. Journal of Facilities Management, 8(4), 285-298 (2010)

4. J. A. Al-khatam, Building Maintenance Cost. King Fahd University of Petroleum \& Minerals (2003).

5. C. P. Au-Yong, A. S. Ali, F. Ahmad, Prediction cost maintenance model of office building based on condition-based maintenance. Eksploatacja I Niezawodnosc - Maintenance And Reliability, 16(2), 319-324 (2014)

6. J. Douglas, Building performance and its relevance to facilities management. Facilities, 14(3/4), 23-32 (1996)

7. N.E. Myeda, S.N. Kamaruzzaman, M. Pitt, Measuring the performance of office buildings 
maintenance management in Malaysia. Journal of Facilities Management, 9(3), 181-199 (2011)

8. I. H. Fakhrudin, M. Z. Suleiman, R. Talib, The need to implement Malaysia's Building and Common Property Act 2007 (Act 663) in building maintenance management. Journal of Facilities Management, 9(3), 170-180 (2011)

9. R. M. W. Horner, M. A. El-Haram, A. K. Munns, Building maintenance strategy: A new management approach. Journal of Quality in Maintenance Engineering, 3(4), 273-280 (1997)

10. H. Krstić, S. Marenjak, Analysis of buildings operation and maintenance costs. Građevinar, 64(4), 293-303 (2012)

11. E. W. M. Lam, A. P. C. Chan, D. W. M.Chan, Benchmarking success of building maintenance projects. Facilities, 28(5/6), 290 - 305 (2012)

12. H. H. Y. Lee, D. Scott, Overview of maintenance strategy, acceptable maintenance standard and resources from a building maintenance operation perspective. Journal of Building Appraisal, 4(4), 269-278 (2008)

13. D. O. Mac-Barango, I. I. Kakulu, Establishing a maintenance cost profile of residential buildings. In S. Laryea, R. Leiringer, \& W. Hughes (Eds.), Procs West Africa Built Environment Research (WABER) Conference 413-425 (2011)

14. N. Mohd-Noor, M. Y. Hamid, A. A. Abdul-Ghani, S. N. Haron, Building Maintenance Budget Determination: An Exploration Study in the Malaysia Government Practice. Procedia Engineering, 20, 435-444 (2011)

15. New Straits Times, "Power back in hands of owners", Strata Living, New South Wales Government, New Straits Times Press, Kuala Lumpur, available at: www.fairtrading.nsm.gov.au (accessed 6 August) (2007)

16. M. F. Mukelas, E. M. Zawawi, S. N. Kamaruzzaman, Z. Ithnin, S. H. Zulkarnain, A Review of Critical Success Factors in Building Maintenance Management of Local Authority in Malaysia. Symposium on Business, Engineering and Industrial Applications, 653-657 (2012)

17. A. L. Olanrewaju, A. Idrus, M. F. Khamidi, Investigating building maintenance practices in Malaysia: a case study. Structural Survey, 29(5), 397-410 (2011)

18. G. R. Ottoman, W. B. Nixon, S. T. Lofgren, Budgeting for Facility Maintenance and Repair I: Methods and Models. Journal of Management in Engineering, 15(4), 71-83 (1999)

19. G. Shabha, A low-cost maintenance approach to high-rise flats. Facilities, 21(13/14), 315-322 (2003)

20. M. K. Sharaidin, F. Salim, Affordable, Performative and Responsive : Designing Affordable Responsive Architectural Prototypes through Physical and Digital Modelling. In International Adaptive Architecture Conference 1-14 (2011)

21. A. Zakaria and S. Hamzah, Pelan Kualiti Elak Projek Hadapi Masalah: Majlis Aset Kebangsaan mampu Tingkatkan Kecekapan Penyenggaraan. Berita Harian, August 15, p.2 (2007)
22. E.M.A. Zawawi, S.N. Kamaruzzaman, A.S. Ali, R. Sulaiman, Assesment of Building Maintenance Managment in Malaysia: Resolving Using a Solution Diagram. Journal of Retail \& Leisure Property 9(4), 349-356 (2010)

23. A.S. Sulaiman, Some Common Maintenance Problems and Building Defects: Our Experiences, Procedia Engineering: In $2^{\text {nd }}$ International Conference on Rehabilitation and Maintenance in Civil Engineering 54 101-108 (2013)

24. S.N. Kamaruzzaman and E.M.A. Zawawi, "Development of facilities management in Malaysia", Journal of Facilities Management, 8 (1), 75-8 (2010)

25. S.A.H. Mustaffa, H. Adnan, K. Jusoff, "Facilities management challenges and opportunity in the Malaysian property sector", Journal of Sustainable Development, 1(2), 79-85 (2008)

26. G. Vijverberg, "Renovation of offices in the Netherlands: reasons, points for attention and obstacles", Proceedings of the CIB Working Commission 070, CABER, Glasgow Caledonian University, September, 728-37 (2002)

27. I.M. Shohet, "Key performance indicators for maintenance of hospital buildings", Proceedings of the CIB Working Commission 070, CABER, Glasgow Caledonian University, September, 79-90 (2002)

28. R.M.R. Mazlan and M.A.H. Mohammed, Identifying Maintenance Issues in Malaysia. In Association Of Schools Of Construction Of Southern Africa (ASOCSA), The Third Built Environment International Conference, At The Westin Grand Cape Town Arabella Quays, Cape Town (p. 13) (2008)

29. C.P. Rydell, Factors affecting maintenance and operating costs in federal public housing projects. Rand, 634, (1970)

30. Y. Asiedu, and P. Gu, Product life cycle cost analysis: state of the art review. International journal of production research, 36(4), 883-908 (1998)

31. B. S. Dhillon, Life cycle costing for engineers. CRC Press (2009)

32. M. Shear, Building Maintenance Management. Virginia, Reston Publishing Co. (1983)

33. P. Wordsworth, Lee's building maintenance management. Wiley-Blackwell (2001)

34. A.O. Lateef, M.F. Khamidi and A. Idrus, Maintenance management of University Building, Proceedings International Symposium on Construction in Developing Economies: Commonalities Among Diversities, Penang, 5-7 October 2009, CIBW107, University Science Malaysia, 578-592 (2009)

35. M.K. Sharaidin, and F. Salim, Affordable, Performative and Responsive : Designing Affordable Responsive Architectural Prototypes through Physical and Digital Modelling. In International Adaptive Architecture Conference, 1-14 (2011)

36. B. Chanter, and P. Swallow, Building maintenance management. John Wiley \& Sons (2008)

37. G.A. John, D.J. Clements-Croome, V. Fairey, \& H.M. Loy, Contextual prerequisites for the 
application of ILS principles to the building services industry. Engineering, Construction and Architectural Management, 12(4), 307-328 (2005)

38. F. Olubodun and T. Mole, Evaluation of defect influencing factors in public housing in the UK. Structural Survey, 17(3), 170-178 (1999)

39. M.A. El-Haram, and M.W. Horner. Factors affecting housing maintenance cost. Journal of Quality in maintenance Engineering, 8(2), 115-123 (2002).

40. S. Assaf, A.M. Al-Hammad, and M. Al-Shihah, M. Effects of faulty design and construction on building maintenance. Journal of performance of constructed Facilities, 10(4), 171-174 (1196)

41. I.H. Fakhrudin, M.Z. Suleiman, \& R. Talib. The need to implement Malaysia's Building and
Common Property Act 2007 (Act 663) in building maintenance management. Journal of Facilities Management, 9(3), 170-180 (2011)

42. R. Holmes, \& C. Droop, "Factors affecting maintenance costs in LA housing", in Brandon, P.S. (Ed.), Building Cost Techniques New Directions, E. \& F.N. Spon, London (1982).

43. A. Ashworth, \& P.L.Y. Au-Yeung, P.L.Y., "The usefulness of maintenance cost records in life life cycle cost prediction", in Spedding, A. (Ed.), Building Maintenance Economics and Management, E. \& F.N. Spon, London, 141-50 (1987) 